ENTREPRENEURSHIP AND SUSTAINABILITY ISSUES

ISSN 2345-0282 (online) http://jssidoi.org/jesi/

2021 Volume 8 Number 4 (June)

http://doi.org/10.9770/jesi.2021.8.4(16)
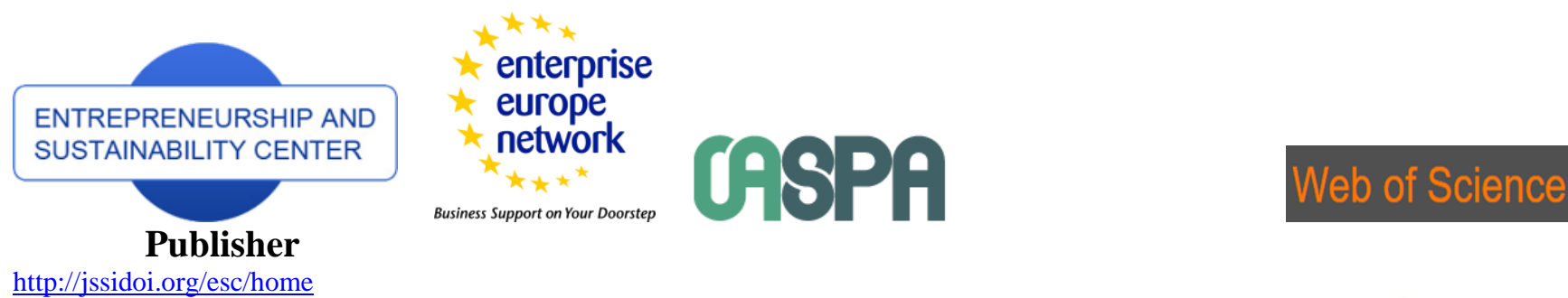

http://jssidoi.org/esc/home

\title{
HIGH PERFORMANCE WORK SYSTEM AND SUSTAINABLE DEVELOPMENT AMONG JORDANIAN SMES: KNOWLEDGE SHARING AS A MODERATOR
}

\author{
Zeyad Alkhazali ${ }^{1}$, Khaleel Al-Daoud ${ }^{2}$, Hareth Alshamayleh ${ }^{3}$, Mazin Aledeinat ${ }^{4}$ \\ ${ }^{1,2}$ Business School, Al-Ahliyya Amman University, Amman 19328, Jordan \\ ${ }^{3}$ Strategic Planning and Institutional Identity Administration, King Faisal University, Alahsa 31982, Saudi Arabia \\ ${ }^{4}$ College of Business and Economics, Qatar University, Doha 2713, Qatar
}

E-mail: ${ }^{\text {z.alkhazali@ammanu.edu.jo; }}{ }^{2}$ k.aldaoud@ammanu.edu.jo; $;{ }^{3}$ halshamayleh@kfu.edu.sa; $;$

Received 11 January 2021; accepted 25 March 2021; published 30 June 2021

\begin{abstract}
The aim of this study is to examine the relationship between high-performance work systems (HPWS), sustainable development, and knowledge sharing in small and medium enterprises (SMEs) in Jordan. In this study it is hypothesized that the ability, motivation, and opportunity (AMO) improving the human resource (HR) practices of SMEs leads to better organizational performance of their employees through the role of knowledge sharing moderation. The results of this study confirm the hypothesis of the causal relationship between AMO practice with sustainable development, and the hypothesis of AMO practice with sustainable development are influenced by knowledge sharing. This study has implications for practice and theory, also can help project managers from these organizations to plan better human resource management (HRM) practices to promote sustainable development through innovation and creative performance of their employees. Therefore, this is one of the first studies to discuss the HRM productivity in AMO practice, and its important role in knowledge sharing.
\end{abstract}

Keywords: sustainable development; innovation performance; high performance work systems; knowledge sharing

Reference to this paper should be made as follows: Alkhazali, Z., Al-Daoud, K., Alshamayleh, H., Aledeinat, M. 2021. High performance work system and sustainable development among Jordanian SMEs: knowledge sharing as a moderator. Entrepreneurship and Sustainability Issues, 8(4), 280-290. http://doi.org/10.9770/jesi.2021.8.4(16)

JEL Classifications: O36, L26

\section{Introduction}

Due to their growing competitiveness, SMEs face modern challenges in monitoring their assets and ensuring accurate information sharing between group individuals, which has prompted increased attention among organizational directors on the importance of effectively monitoring human assets on common premises to ensure that employees proceed to include an appreciation of the objectives of the organization (Jyoti and Rani, 2017; 


\section{ENTREPRENEURSHIP AND SUSTAINABILITY ISSUES}

ISSN 2345-0282 (online) http://jssidoi.org/jesi/

2021 Volume 8 Number 4 (June)

http://doi.org/10.9770/jesi.2021.8.4(16)

(Turner and Ledwith, 2018). Human assets are one of the important resources of organizations of various types and segments.

Prado and Sapsed (2016) define SMEs as "organizations that serve clients, develop specialized projects such as systems development engineering, coaching, and organization and consulting, and create temporary arrangements and systems" (p. 1795).

Knowledge as a key competency for an organization that contributes to making organizational implementation progress and improvement sustainable (Santoro et al., 2019c). The development and improvement supported in today's knowledge -based society stems from the ability to disseminate knowledge (Vrontis and Christofi, 2019). The ability of employees to transfer knowledge to each other may be a key factor in making a difference for organizational implementation progress and for creating worthy progress (Santoro et al., 2019a).

While investigating writings on HRM practices and AMO practices, Pak et al. (2019) describe the development of existing writing on the efficiency and impact of HRM practices on AMO applications. For this reason, not being able to make accurate choices about the future to inquire or investigate openings cannot decide which mediation would be more beneficial for those in SMEs characterized by a chain of budget, quality, time and toll (PrietoPastor et. Al., 2018; Alkhazali et al., 2019). In development, there is no research on mediators and mediators on the relationship between AMO application and implementation of progress, especially in SME.

Therefore, the aim is to explore the impact of HPWS on sustainable development among SMEs using AMO practices. Next, to investigate the role of knowledge sharing in this relationship. This study uses a quantitative method with a survey approach and was conducted on employees working in SME Jordan. Moreover, this study contributes to the literature on HPWS (AMO practice), enhancing our knowledge of HPWS by conceptualizing support for the role of knowledge sharing interventions in supporting exceptional sustainable development through the innovative performance of employees working at SME Jordan.

\section{Theoretical background}

Research on sustainable development has long recognized key drivers and opportunities for progress (Santoro et al., 2018, 2019b; Portela, 2020). The basis of this victory variable is what we refer to as human progress administration, which appears to lead and organize improved individuals in SMEs (Bogers et al., 2018). Past research in the field of HRM has found a relationship between employee AMO practices and employment, using the focal point of AMO preparation, Appelbaum et al. (2000) emerged that organizations can have a positive impact on organizational performance by ensuring that all delegates have AMO practices to perform their work efficiency. Elbaz et al. (2018) defined competence as "the talents, knowledge, skills, competencies and experience required to complete a task" and motivation as "the desire (or level of motivation) to do so". The ability of a company to "create or acquire new knowledge and information, and then apply and assimilate that knowledge, is a function of the collective ability of employees to recognize, learn and share this knowledge" (Ferraris et al., 2017). Motivation in similar situations allows these employees to develop and expand this knowledge in cognitive communication and leads to better performance (Tho and Trang, 2015). The combination of AMO practices has been identified as important in enhancing organizational innovation. Messersmith and Guthrie (2010) describe development as the creation and expansion of modern administrations, items, and forms that contribute to the creation or increase of appreciation for an organization. Analysts use AMO practices to clarify the relationship between HPWS and sustainable development. It has been hypothesized and tested that HPWS enhances the capabilities, information, and capabilities of employees to give them the ability to improve in terms of performance. By implementing AMO practices, the organization energizes its representatives to demonstrate good performance with the help of engaging HRM practices. 


\section{ENTREPRENEURSHIP AND SUSTAINABILITY ISSUES}

ISSN 2345-0282 (online) http://jssidoi.org/jesi/

2021 Volume 8 Number 4 (June)

http://doi.org/10.9770/jesi.2021.8.4(16)

Organizations also provide opportunities for their representatives to participate in the advancement of organizational objectives and approach progress, then empower them to create unapplied thinking that is the basis of organizational implementation. Although there has been extensive writing on HRM practices and innovation performance, analysts have ultimately sought to combine these two queries on flow (Alkhazali et al., 2020). The following areas offer some assumptions about the influence of encouraging communication and data trade between AMO practices and sustainable development for SMEs.

\section{Hypothesis development}

The ability, motivation, and opportunity improve HR practices and sustainable development

The impact of AMO practices on sustainable development with inventive outcomes within the created countries has been widely considered. Cabello-Medina et al. (2011) to establish an interface between the practice and development of HRM by taking cases from Spanish organizations with human and social capital divisions. Camelo-Ordaz et al. (2011) built a relationship between HRM practice and development implementation through knowledge sharing. A number of people think they have examined this relationship in an Asian setting. Alkhazali et al. (2020) found that HRM practices lead to superior development outcomes, which in turn lead to advanced implementation. Argote et al. (2003) highlighted the part of AMO practice and knowledge management in advancing organizational implementation. In their consideration, Turner and Pennington (2015) concluded that inspiration and opportunity are highly related to information trading, but their findings failed to establish a positive relationship between talent and data trading. In expansion, analysts such as Chowhan (2016) argue that the experience of creating HR capabilities encompasses a critical impact on organizational performance through the impact of organizational progress interventions. But in general, Jiang et al. (2012) found an important interface between AMO practices and organizational performance.

H1. There is a positive relationship between HPWS (AMO practices) and sustainable development among Jordanian SMEs.

H1a. There is a positive relationship between ability enhancing HR practices and sustainable development among Jordanian SMEs.

H1b. There is a positive relationship between motivation enhancing HR practices and sustainable development among Jordanian SMEs.

H1c. There is a positive relationship between opportunities enhancing HR practices and sustainable development among Jordanian SMEs.

\section{The moderating role of knowledge sharing}

The literature centers on the importance of knowledge sharing in organizations (Dezi et al., 2019), and the impact of knowledge sharing is poorly examined, information sharing has been linked to organizational performance outcomes as customer benefits increase, decrease in generation cycle (e.g., Ma et al., 2008) and feasible improvements (Papa et al., 2018b; Santoro et al., 2018). Knowledge sharing can be a key preparation in information management methodologies (Alkhazali et al., 2019) and has been examined at the people and organizational levels (Alkhazali et al., 2019; Ferraris et al., 2018). At the individual level, knowledge sharing is characterized by the extent to which employees share the information they obtain with others in the organization (Teh and Yong, 2011). These include open knowledge that can be collected and stored in the form of official records, and confidential information that is difficult to apply (Shah et al., 2007; Nonaka, 1994). If employees do not share their information with others, they will not be able to contribute to more pressing organizational interests when representatives turn to competitors (Ma et al., 2008) and in this way have little valuable information about themselves (Curado et al., 2017). Human resource management style, the transfer of innovation directly affects the sustainability of the company (Laužikas, Miliūtè, 2020; Laužikas et al., 2021).

Along with Shipton et al. (2005), HPWS empowers organizations and delegates to build successful and deliberate environments and platforms that consider near acquisition, acquisition and sharing of knowledge and play a role 
in improving innovative performance. Wright et al. (2001) reaffirmed the role of HPWS in providing a robust culture where employees share their knowledge and in turn improve organizational performance.

According to Wang and Noe (2010), if AMO practices seek more grounded employee behavior, other delegates will benefit enormously from this knowledge, which can have a positive and critical impact on organizational performance. Thus, representative knowledge sharing behaviors incorporate a strong impact on organizational performance, because simple and explicit individual and organizational knowledge (Alkhazali et al., 2019) must be incorporated into organizational rules to value the organization. Agreed to ask about Curado et al., (2017) and Xue et al. (2011), this thinking uses a knowledge -based approach and uses repetitive and representative interest in knowledge exchange. Knowledge exchange is seen to be essentially related to organizational performance (Muduli and McLean, 2020).

H2: knowledge sharing moderates the relationship between HPWS (AMO practices) and sustainable development among Jordanian SMEs.

H2a. Knowledge sharing moderates the relationship between ability enhancing HR practices and sustainable development among Jordanian SMEs.

H2b. Knowledge sharing moderates the relationship between motivation enhancing HR practices and sustainable development among Jordanian SMEs.

H2c. Knowledge sharing moderates the relationship between opportunity enhancing HR practices and sustainable development among Jordanian SMEs.

\section{Method}

Based on an extensive review of the available literature, this study identified three independent variables: ability to improve HR practice, motivation to improve HR practice and opportunity to improve HR practice. The aspect of the study -dependent variable was sustainable development among Jordanian SMEs. In addition, moderator variables have been proposed to influence the relationship between independent variables and dependent variables. Essentially, the moderator used in this study was knowledge sharing. The relationships of these variables will all be examined against the assumptions of the case. Figure 1 below illustrates the schematic framework and the proposed relationship between the variables.

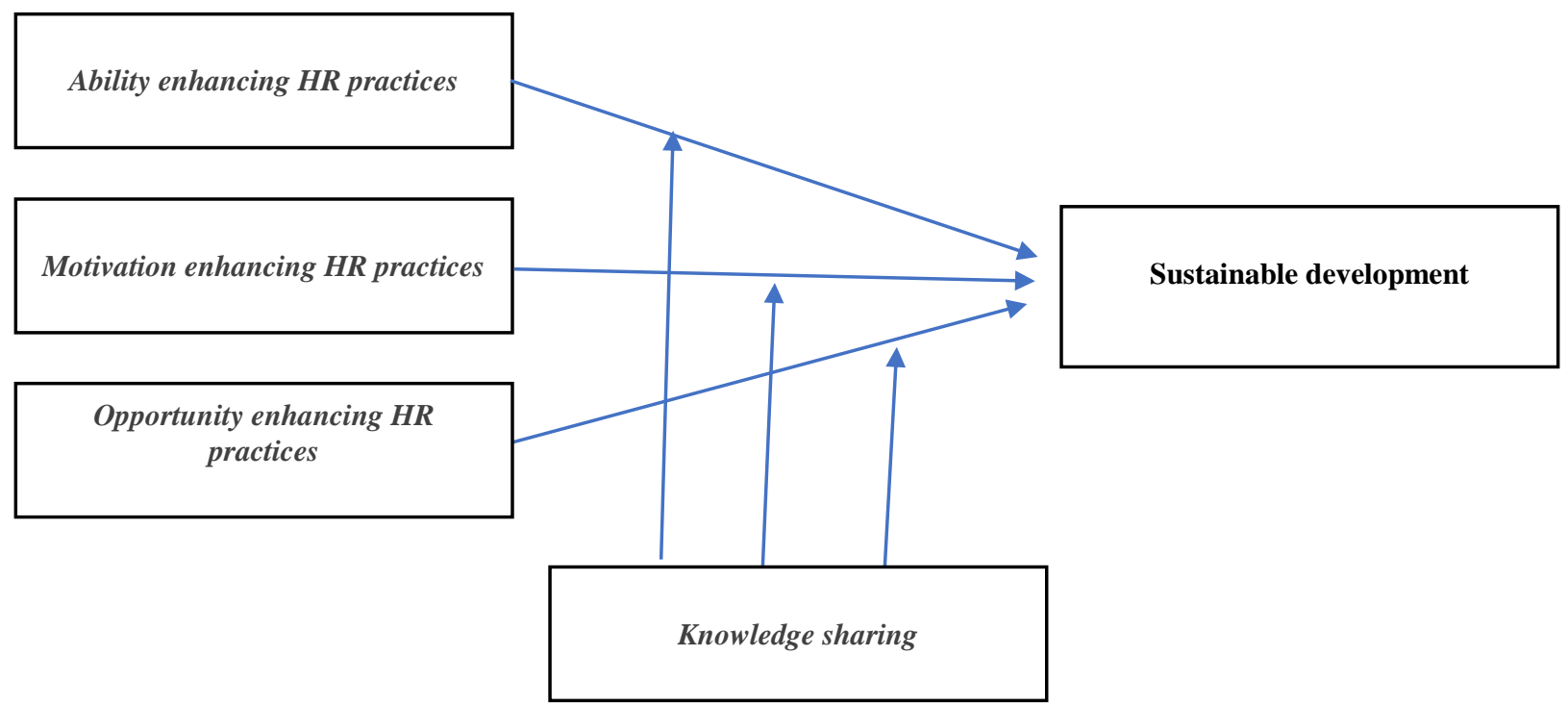

Figure 1. The Theoretical Framework of the Research 


\section{ENTREPRENEURSHIP AND SUSTAINABILITY ISSUES}

ISSN 2345-0282 (online) http://jssidoi.org/jesi/

2021 Volume 8 Number 4 (June)

http://doi.org/10.9770/jesi.2021.8.4(16)

According to Figure 1, there are two alternative models that reflect the relationships described in the framework, which can be further enriched by testing the alternative models. The alternative models presented here serve as examples of possible relationships and explain the frameworks put forward when presenting the various hypotheses to be tested. This alternative model is often referred to in the literature as the "relationship" between HPWS (AMO practices) and sustainable development.

Based on the proposed framework, several sets of hypotheses are prepared. This hypothesis will forge a relationship between HPWS (AMO practices) and sustainable development, and will test the role of knowledge sharing proposed in this relationship.

\section{Measures}

This research uses survey research tools as its quantitative approach, known as appropriate data collection instruments. Each variable to be studied in this study is a continuous variable. This is HPWS (AMO practice), knowledge sharing as a moderation variable and sustainable development as a dependent variable (Zikmund et al., 2010).

Moreover, because of the suitability of quantitative research data with numbers, questionnaires are the best approach to collect data appropriate to these characteristics. This is more appropriate as this study is interested in capturing the opinions of SME Jordan employees. This indicates that the information expected by the respondents can be obtained from the individual's reflection on the reality of the workplace and its variations.

\section{Population}

The population includes all 14 five-star hotels in Amman which are: Millennium Hotel Amman, Le Royal, Bristol Hotel, Sheraton Amman AL-Nabil Hotel and Towers, Intercontinental Jordan Hotel, Crowne Plaza Amman, The Regency Palace Hotel, Holiday Inn Hotel, Kempiski Hotel Amman, Four Seasons Hotel, Landmark Amman Hotel, Le Meridian Amman Hotel, Amman Marriott Hotel, and Grand Hyatt Amman Hotel. The following hotel information and data were included in the study: Landmark Amman Hotel, Kempiski Hotel Amman, The Regency Palace Hotel, Le Meridian Amman Hotel, Holiday Inn Hotel, Amman Marriott Hotel, Intercontinental Jordan Hotel, Bristol Hotel.

\section{Sampling and sampling method}

Researchers studied 8 of 14 five -star hotels as a sample. The study consisted of a sample unit consisting of 176 front office employees; including front desk staff, reception operators, chief of staff, director of guest relations at the eight hotels previously reviewed; A total of 20 questionnaires were distributed in each hotel dated February 2020. 122 of these questionnaires could be used with a response rate of $69.3 \%$ for data collection purposes.

Researchers have made the previously mentioned hotels as examples of five-star hotels in Amman, as the HR department at other five-star hotels considers the required data to be confidential and states that disclosing such data is against hotel policy. These hotels are Crowne Plaza Amman, Four Seasons Hotel, Grand Hyatt Amman Hotel, Le Royal, Sheraton Amman AL-Nabil Hotel and Towers and Millennium Hotel Amman.

Proportional random sampling method to cover all hotels effectively, this sampling method also improves sample representation by reducing sampling errors. Additional analysis provides opportunities for data filtering and cleaning as well as control for unresponsive data, and some forms of data collection errors (Krejcie and Morgan, 1970).

In addition, items answering questions related to HPWS (AMO practices), knowledge sharing, and sustainable development were included in the questionnaire section. The development of survey instruments is guided by the 


\section{ENTREPRENEURSHIP AND SUSTAINABILITY ISSUES}

ISSN 2345-0282 (online) http://jssidoi.org/jesi/

2021 Volume 8 Number 4 (June)

http://doi.org/10.9770/jesi.2021.8.4(16)

relevant literature, and adaptations to relevant items in the past, if appropriate. A standard 5 -point Likert response evaluation scale was used to measure dependent variables, independent variables, and moderate variables.

\section{Coefficient of determination (R2)}

In addition to suitability and importance assessments, another relationship assessment measure in the PLS-SEM model is the R-square phase assessment or determinant factor (Hair et al., 2014). $R \wedge 2$ is a measure of model prediction accuracy, calculated as the rectangular correlation between the predicted endogenous construction and the actual value (Hair et al., 2014). The value of $\mathrm{R}^{\wedge} 2$ reflects the combined effect of exogenous latent variables on latent endogenous variables (Hair et al., 2010; Hair et al., 2014). The values of $\mathrm{R} \wedge 2$ for the endogenous variables of the direct link model are shown in Table 1 below.

Table 1. Coefficient of Determination (R-Square)

\begin{tabular}{cc}
\hline Endogenous variable & R-square \\
\hline Sustainable development & 0.75 \\
\hline
\end{tabular}

Chin (1998) suggested that $\mathrm{R} \wedge 2$ values of 0.67, 0.33, and 0.19, respectively, were considered important, moderate, and weak, or rejected in PLS-SEM modeling. Table 1 of the exogenous latent constructs in this study (i.e., HPWS (AMO practice)) illustrates 75 percent of the variance in sustainable development. Following Chin's (1998) suggestion, the value of $\mathrm{R}^{\wedge} 2$ described is very close to a large influence. This suggests that 75 percent of sustainable development depends on the independent variables considered in this study. The remaining 25 percent can be explained by other factors.

\section{Hypotheses testing for direct relationships}

The first step to test the direct relationship hypothesis is to run the PLS algorithm, which allows the researcher to create path coefficients to determine the relationship between the independent and dependent variables in this study. The second step is the opener string to make a value of t to check the importance of this relationship, there are various suggestions on how the opener string can be used. For example, Hair et al. (2013), shoelaces can be run with 500 sub-patterns, Hair et al. (2014) recommended 5,000. This work was published by Hair et al. (2014) used 5,000.

The results of the structural model of this study based on the direct relationship between the independent variables and the dependent variables are shown in Table 2 below. These results were interpreted using road connection coefficients (Beta), standard error (SE), t values (T statistics) and $\mathrm{P}$ values.

Table 2. Structural Model Output for Hypotheses Testing

\begin{tabular}{|c|c|c|c|c|c|c|}
\hline Hypotheses & Relationship & Path coef. & Stan. erro. & T Stat. & P valu. & Comm. \\
\hline H1 & $\ldots$ & $\ldots$ & $\ldots$ & $\ldots$ & $\ldots$ & $\ldots$ \\
\hline H1a & AHR -> SD & 0.189 & 0.053 & 3.568 & 0.000 & Accept \\
\hline H1b & MHR -> SD & 0.197 & 0.051 & 3.593 & 0.000 & Accept \\
\hline H1c & OHR -> SD & 0.188 & 0.054 & 3.549 & 0.000 & Accept \\
\hline
\end{tabular}

\section{Assessment of the effect size for direct relationships}

In addition to estimating the $\mathrm{R}^{\wedge} 2$ value of a model -dependent variable (e.g., sustainable development), changes in the $\mathrm{R} \wedge 2$ value are used when a particular independent variable is removed from the model to assess whether the variable is eliminated. on the variables that depend on latent sustainable development. This dimension is called the impact dimension (Hair et al., 2014). The magnitude of the effect is determined by the relative effect of a given independent variable on the dependent variable based on the change in the value of $R \wedge 2$ due to the 
ENTREPRENEURSHIP AND SUSTAINABILITY ISSUES

ISSN 2345-0282 (online) http://jssidoi.org/jesi/

2021 Volume 8 Number 4 (June)

http://doi.org/10.9770/jesi.2021.8.4(16)

reduction (Chin, 1998). As a result, the effect size was measured by Cohen's formula (Hair et al., 2014; Cohen, 1988).

given as:

Where:

$$
\mathrm{F}^{2}=\frac{\mathrm{R}^{2} \text { included }-\mathrm{R}^{2} \text { excluded }}{1-\mathrm{R}^{2} \text { included }}
$$

Formula 1. F-square value

$F^{2}$ : is the F-square value that determines the effect size of a specific independent variable on the dependent variable.

$R^{2}$ included: is the $R^{2}$ value of the dependent variable before omitting a particular independent variable.

$R^{2}$ excluded: represents the changes in the $R^{2}$ value of the dependent variable after excluding a particular independent variable from a model.

Based on the Formula 1 , the $\mathrm{F}^{2}$ values of $0.02,0.15$, and 0.35 , indicates small, medium, and large effects respectively (Cohen, 1988).

Table 3. Assessment of the Effect Size (F-Square)

\begin{tabular}{|c|c|c|c|}
\hline $\begin{array}{c}\text { Independent } \\
\text { variables }\end{array}$ & $\mathbf{R}^{\mathbf{2}}$ incl. & $\mathbf{R}^{\mathbf{2}}-$ excl. & Effect size \\
\hline AHR & 0.748 & 0.650 & 0.388 \\
\hline MHR & 0.748 & 0.654 & 0.373 \\
\hline OHR & 0.748 & 0.691 & 0.226 \\
\hline
\end{tabular}

Table 3 is the result of a large -scale evaluation of the effect of each independent variable on the dependent variable. The direct relationship is that all independent variables that have a significant influence on the dependent variables have moderate and large effects on sustainable development.

\section{Hypotheses testing for moderating effect}

In this study, the effects of knowledge sharing moderation were tested in the relationship between HPWS (AMO practices) and sustainable development. Table 4 shows the findings of the moderate effect test.

Table 4. Results of Moderating Effect Test

\begin{tabular}{|c|c|c|c|c|c|c|}
\hline Hypotheses & Relationship & Coef. & T-valu. & P-valu. & Level of sig. & Comm. \\
\hline H2 & $\ldots$ & $\ldots$ & $\ldots$ & $\ldots$ & $\ldots$ & $\ldots$ \\
\hline H2a & KS* AHR -> SD & 0.121 & 3.658 & 0.002 & $* * *$ & Accepted \\
\hline H2b & KS* MHR -> SD & 0.087 & 2.437 & 0.035 & $* *$ & Accepted \\
\hline H2c & KS* OHR -> SD & 0.291 & 0.979 & 0.385 & - & Rejected \\
\hline
\end{tabular}

Table 4 shows the results of hypotheses examining the moderate effects of knowledge sharing on the relationship between HPWS (AMO practices) and sustainable development. In the PLS-SEM analysis, a knowledge-sharing effect exists if the interaction path is significant, meaning that the t-statistical effect of the interaction must be 1.64 or 1.96 and above to be significant using one or two tails each (Hair et al., 2010).

\section{Discussion and conclusion}

\section{The relationship between HPWS (AMO practices) and sustainable development}

The HPWS high -performance work system (AMO practice) as a success factor in relationship management has a positive impact on sustainable development among Jordanian SMEs, as expressed in hypothesis H1 (H1a, H1b, and H1c). The results of this correlation, as reported in Table 3, were at a significance level of 0.001, with band coefficients (AHR 0.189, MHR 0.197 and OHR 0.188), T-statistics and P values (AHR was $\mathrm{t}=3,568(\mathrm{P}<0.000)$, 


\section{ENTREPRENEURSHIP AND SUSTAINABILITY ISSUES}

ISSN 2345-0282 (online) http://jssidoi.org/jesi/

2021 Volume 8 Number 4 (June)

http://doi.org/10.9770/jesi.2021.8.4(16)

MHR is $t=3.593(\mathrm{P}<0.000)$ and OHR is $\mathrm{t}=3.549(\mathrm{P}<0.000)$ ). These results indicate that HPWS (AMO practice) is considered to be the most important determinant of sustainable development.

\section{The effects of HPWS (AMO practices) on sustainable development are Influenced by the knowledge sharing}

The effect of knowledge sharing moderation on the relationship between HPWS (AMO practices) and sustainable development, as expressed in hypothesis $\mathrm{H} 2(\mathrm{H} 2 \mathrm{a}, \mathrm{H} 2 \mathrm{~b}$ and $\mathrm{H} 2 \mathrm{c})$. These results support the hypothesis as shown in Table 4, at a significance level of 0.001 (AHR is Coef $=0.121, t=3.658(p>0.002)$, MHR is Coef $=0.087, t=$ $2.437(\mathrm{p}>0.035)$ and OHR is Coef $=0.291, \mathrm{t}=0.979(\mathrm{p}>0.385))$.

These findings indicate that the effect of knowledge sharing moderation on the relationship between HPWS (AMO practices) and sustainable development is significant. However, according to Hair et al. (2010), H3c both $\mathrm{t}$-statistics and p-values were insignificant. Therefore, the $\mathrm{H} 3 \mathrm{c}$ hypothesis, which states that knowledge sharing moderates the relationship between opportunities to improve HR practices and sustainable development is not accepted.

This paper highlights the complexity of management tasks and recommends that Jordan take a knowledge sharing perspective. Resources can be provided by lecturers, staff and SME who require an interactive approach that integrates these resources. If the proposal is implemented to realize the vision of the future, Jordan will benefit.

Future research may be based on the following considerations: increase the research population by covering the entire SME sector. Alternatively, take evidence from other industries and increase the number of observations using larger sample sizes and longer data periods. The relationship between HPWS (AMO practices) and sustainable development can be further explained if the researcher subsequently conducts research by including additional variables, including other dimensions of knowledge sharing in terms of SME perceptions and operations. Changing knowledge sharing from a moderate variable to an intermediate variable or even an independent variable can also change outcomes and relationships. As SMEs are still growing in Jordan, performance appraisals should be conducted from time to time to take corrective action if necessary.

\section{References}

Alkhazali, Z., Abu-Rumman, A., Khdour, N., \& Al-Daoud, K. (2020). Empowerment, HRM practices and organizational performance: a case study of Jordanian commercial banks. Entrepreneurship and Sustainability Issues, 7(4), 2991. https://doi.org/10.9770/jesi.2020.7.4(28)

Alkhazali, Z., Aldabbagh, I., \& Abu-Rumman, A. (2019). Tqm potential moderating role to the relationship between hrm practices, Km strategies and organizational performance: The case of Jordanian banks. Academy of Strategic Management Journal, 18(3), 1-16.

Appelbaum, E., Bailey, T., Berg, P., \& Kalleberg, A. (2000), Manufacturing Competitive Advantage: The Effects of High Performance Work Systems on Plant Performance and company Outcomes, Cornell University Press, New York.

Argote, L., McEvily, B., \& Reagans, R. (2003). Managing knowledge in organizations: an integrative framework and review of emerging themes. Management Science, 49(4), 571-582.

Bogers, M., Foss, N.J., \& Lyngsie, J. (2018). The 'human side's of open innovation: the role of employee diversity in firm-level openness. Research Policy, 47(1), 218-231. 


\section{ENTREPRENEURSHIP AND SUSTAINABILITY ISSUES}

ISSN 2345-0282 (online) http://jssidoi.org/jesi/

2021 Volume 8 Number 4 (June)

http://doi.org/10.9770/jesi.2021.8.4(16)

Cabello-Medina, C., Lopez-Cabrales, A., \& Valle-Cabrera, R. (2011). Leveraging the innovative performance of human capital through HRM and social capital in Spanish firms. InternationalJournal of Human Resource Management, 22(4), 807-828. https://doi.org/10.1080/09585192. 2011.555125

Camelo-Ordaz, C., Garcia-Cruz, J., Sousa-Ginel, E., \& Valle-Cabrera, R. (2011). The influence of human resource management on knowledge sharing and innovation in Spain: the mediating role of affective commitment. The International Journal of Human Resource Management, 22(7), 1442-1463.

Chin, W. W. (1998). The partial least squares approach to structural equation modeling. Modern methods for business research, 295(2), 295-336. https://doi.org/10.1108/ebr-10-2013-0128

Chowhan, J. (2016). Unpacking the black box: understanding the relationship between strategy, HRM practices, innovation and organizational performance. Human Resource Management Journal, 26(2), 112-133.

Cohen, S. (1988). Perceived stress in a probability sample of the United States. In S. Spacapan \& S. Oskamp (Eds.), The Claremont Symposium on Applied Social Psychology. The social psychology of health (p. 31-67). Sage Publications, Inc.

Curado, C., Oliveira, M., Maçada, A.C.G., \& Nodari, F. (2017). Teams' innovation: getting there through knowledge sharing and absorptive capacity. Knowledge Management Research \& Practice, 15(1), 45-53.

Dezi, L., Ferraris, A., Papa, A. \& Vrontis, D. (2019). The role of external embeddedness and knowledge management as antecedents of ambidexterity and performances in Italian SMEs. IEEE Transactions on Engineering Management. https://doi.org/10.1109/TEM.2019.2916378

Elbaz, A.M., Agag, G.M. \& Alkathiri, N.A. (2018). How ability, motivation and opportunity influence travelagents performance: the moderating role of absorptive capacity. Journal of Knowledge Management, 22(1), 119-141. https://doi.org/10.1108/JKM-07-2017-0308

Ferraris, A., Santoro, G. \& Bresciani, S. (2017). Open innovation in multinational companies' subsidiaries: the role of internal and external knowledge. European Journal of International Management, 11(4), 452-468.

Ferraris, A., Santoro, G., Bresciani, S. \& Carayannis, E.G. (2018). HR practices for explorative and exploitative alliances in smart cities: evidences from smart city managers' perspective. Management Decision, 56(6), 1183-1197. https://doi.org/10.1108/MD-04-2017-0384

Hair Jr, J., Sarstedt, M., Hopkins, L., \& G. Kuppelwieser, V. (2014). Partial least squares structural equation modeling (PLS-SEM) An emerging tool in business research. European Business Review, 26(2), 106-121. https://doi.org/10.1108/ebr-10-2013-0128

Hair, J. F., Ringle, C. M., \& Sarstedt, M. (2013). Partial least squares structural equation modeling: Rigorous applications, better results and higher acceptance. Long range planning, 46(1-2), 1-12. https://doi.org/10.1016/j.lrp.2013.01.001

Hair, J., Black, W., Babin, B.A., Anderson, R., \& Tatham, R. (2010). RE Multivariate Data Analysis. A Global Perspective: Pearson Prentice Hall. https://doi.org/10.2307/2348783

Jiang, K., Lepak, D.P., Hu, J. \& Baer, J.C. (2012). How does human resource management influence organizational outcomes? A metaanalytic investigation of mediating mechanisms. Academy of Management Journal, 55(6), 1264-1294, https://doi.org/10.5465/amj.2011.0088

Jyoti, J., \& Rani, A. (2017). High performance work system and organisational performance: role of knowledge management. Personnel Review, 46(8), 1770-1795. https://doi.org/10.1108/PR-10-2015-0262

Krejcie, R. V., \& Morgan, D.W. (1970). Determining sample size for research activities. Educational and psychological measurement, 30(3), 607-610. https://doi.org/10.1177/001316447003000308

Laužikas, M., \& Miliūtè, A. (2020). Human resource management effects on sustainability of high-tech companies: what Lithuania and South Korea can learn from each other. Insights into Regional Development, 2(2), 562-579. https://doi.org/10.9770/IRD.2020.2.2(5)

Laužikas, M., Miliūtè, A., \& Khalili, M. (2021). Internationalization impacts on team innovation in Lithuanian high-tech firms. Insights into Regional Development, 3(1), 41-64. https://doi.org/10.9770/IRD.2021.3.1(3)

Ma, Z., Qi, L. \& Wang, K. (2008). Knowledge sharing in Chinese construction project teams and its affecting factors. Chinese Management Studies, 2(2), 97-108. https://doi.org/10.1108/17506140810882234 


\section{ENTREPRENEURSHIP AND SUSTAINABILITY ISSUES}

ISSN 2345-0282 (online) http://jssidoi.org/jesi/

2021 Volume 8 Number 4 (June)

http://doi.org/10.9770/jesi.2021.8.4(16)

Messersmith, J.G. \& Guthrie, J.P. (2010). High performance work systems in emergent organizations: implications for firm performance. Human Resource Management, 49(2), 241-264. https://doi.org/10.1002/hrm.20342

Muduli, A., \& McLean, G.N. (2020). Training transfer climate: examining the role of high performance work system and organizational performance in the power sector of India. Benchmarking. https://doi.org/10.1108/BIJ-01-2020-0039

Pak, K., Kooij, D.T., De Lange, A.H. \& Van Veldhoven, M.J. (2019). Human Resource Management and the ability, motivation and opportunity to continue working: a review of quantitative studies. Human Resource Management Review, 29(3), 336-352.

Papa, A., Santoro, G., Tirabeni, L. \& Monge, F. (2018b). Social media as tool for facilitating knowledge creation and innovation in small and medium enterprises. Baltic Journal of Management, 13(3), 329-344. https://doi.org/10.1108/BJM-04-2017-0125

Prado, P. \& Sapsed, J. (2016). The anthropophagic organization: how innovations transcend the temporary in a project-based organization. Organization Studies, 37(12), 1793-1818. https://doi.org/10.1177\%2F0170840616655491

Portela, J. (2020). El Derecho en tiempos de crisis (Law in times of crisis: An approach to notions of truth and justice). Jurídicas CUC, 16(1), 269-286. https://doi.org/10.17981/juridcuc.16.1.2020.11 -1

Prieto-Pastor, I., Martın-Perez, V. \& Martın-Cruz, N. (2018). Social capital, knowledge integration and learning in project-based organizations: a CEO-based study. Journal of Knowledge Management, 22(8), 1803-1825. https://doi.org/10.1108/JKM-05-2017-0210

Santoro, G., Bresciani, S. \& Papa, A. (2018). Collaborative modes with cultural and creative industries and innovation performance: the moderating role of heterogeneous sources of knowledge and absorptive capacity. Technovation https://doi.org/10.1016/j.technovation.2018.06.003

Santoro, G., Ferraris, A. \& Winteler, D.J. (2019a). Open innovation practices and related internal dynamics: case studies of Italian ICT SMEs. EuroMed Journal of Business, 14(1), 47-61.

Santoro, G., Mazzoleni, A., Quaglia, R. \& Solima, L. (2019b). Does age matter? The impact of SMEs age on the relationship between knowledge sourcing strategy and internationalization. Journal of Business Research https://doi.org/10.1016/j.jbusres.2019.05.021

Santoro, G., Thrassou, A., Bresciani, S. \& Del Giudice, M. (2019c). Do knowledge management and dynamic capabilities affect ambidextrous entrepreneurial intensity and firms' performance? IEEE Transactions on Engineering Management. https://doi.org/10.1109/TEM.2019.2907874

Shah, H., Eardley, A. \& Wood-Harper, T. (2007). ALTAR in action: knowledge management. European Journal of Information Systems, 16(6), 771-779. https://doi.org/10.1057/palgrave.ejis.3000721

Teh, P.-L. \& Yong, C.-C. (2011). Knowledge sharing in IS perspective organizational behavior's perspective. Journal of Computer Information Systems, 51(4), 11-21. https://doi.org/10.1080/08874417.2011.11645497

Tho, N.D. \& Trang, N.T.M. (2015). Can knowledge be transferred from business schools to business organizations through in-service training students? SEM and fsQCA findings. Journal of Business Research, 68(6), 1332-1340. https://doi.org/10.1016/j.jbusres.2014.12.003

Turner, J.R. \& Ledwith, A. (2018). Project management in small to medium-sized enterprises: fitting the practices to the needs of the firm to deliver benefit. Journal of Small Business Management, 56(3), 475-493. https://doi.org/10.1111/jsbm.12265

Turner, T. \& Pennington, W.W. (2015). Organizational networks and the process of corporate entrepreneurship: how the motivation, opportunity, and ability to act affect firm knowledge, learning, and innovation. Small Business Economics, 45(2), 447-463.

Vrontis, D. \& Christofi, M. (2019). R\&D internationalization and innovation: a systematic review, integrative framework and future research directions. Journal of Business Research. https://doi.org/10.1016/j.jbusres.2019.03.031

Wang, S. \& Noe, R.A. (2010). Knowledge sharing: a review and directions for future research. Human Resource Management Review, 20(2), 115-131.

Wright, P.M., Dunford, B.B. \& Snell, S.A. (2001). Human resources and the resource based view of the firm. Journal of Management, 27(6), 701-721. 


\section{ENTREPRENEURSHIP AND SUSTAINABILITY ISSUES}

ISSN 2345-0282 (online) http://jssidoi.org/jesi/

2021 Volume 8 Number 4 (June)

http://doi.org/10.9770/jesi.2021.8.4(16)

Xue, Y., Bradley, J. \& Liang, H. (2011). Team climate, empowering leadership, and knowledge sharing. Journal of Knowledge Management, 15(2), 299-312.

Zikmund, W. G., Babin, B. J., Carr, J. C., \& Griffin, M. (2010). Business Research Methods, South-Western, Cengage Learning. Mason, $\mathrm{OH}$.

\section{Zeyad ALKHAZALI}

ORCID ID: https://orcid.org/0000-0001-8693-6253

Khaleel AL-DAOUD

ORCID ID: https://orcid.org/0000-0003-2318-2735

Hareth ALSHAMAYLEH

ORCID ID: https://orcid.org/0000-0002-9588-1028

Mazin ALEDEINAT

ORCID ID: https://orcid.org/0000-0002-9487-0773

Make your research more visible, join the Twitter account of ENTREPRENEURSHIP AND SUSTAINABILITY ISSUES: @Entrepr69728810

Copyright (C) 2021 by author(s) and VsI Entrepreneurship and Sustainability Center

This work is licensed under the Creative Commons Attribution International License (CC BY).

http://creativecommons.org/licenses/by/4.0/

(c) (†) Open Access 